\title{
Gender Dynamics for Advancement: Annexing Women's Potentials for Sustainable Development through (Yorùbá) Nollywood
}

\author{
Adagbada Olufadekemi PhD \\ Department of Nigerian \& Foreign Languages \& Literatures, Faculty of Arts, Olabisi Onabanjo \\ University, Ago-Iwoye, Ogun State, Nigeria
}

\begin{abstract}
In the past, women, in virtually all the nations of the world, were severely oppressed and marginalized. The extent and forms of the oppression however differ along cultural lines. Over the years, there have been agitating moves to repel the oppression, albeit in different ways under divergent nomenclatures. In present times globally, women are witnessing very less oppression and denigration by enjoying (near) equal rights with their male counterpart. What this study is set to examine is that if the female before now was denied asserting her rights and capabilities to the development of her society, now that she is not suffering oppression, in what ways can her sexuality be annexed, such that she can contribute her quotato the sustainable development of her society and the world at large. We have exemplified the roles of women in the metamorphic development of Yoruba drama, especially the contemporary film era to drive home the point that with her 'scared' mien and composition, the female gender can purpose fully write, produce, act and direct films that can aid Nigeria in solving her present socio-political challenges that are threatening her very existence. Our theoretical framework is a combination of Womanism in the view of Hundson-Weems (1994) and Kolawole (1997) and Development and Media theory as opined by McQuail (2000). Our suggestions are that government and non-profit organizations in Nigeria should encourage female film producers by commissioning film projects to them and assist them financially with self-productions. Female producers on the hand are called upon to be patriotic by writing scripts, producing and acting films that can assist in effecting positive change towards a unified, peaceful and virile nation, in their viewers.
\end{abstract}

Keywords: Women, Paradigm Shift, Film, Specialization, Development.

\section{INTRODUCTION}

'Development' as a phenomenal issue, is very complex. As a concept, it cuts across several disciplines, but it is easily located in virtually all human enterprises. To develop means to come to, or improve gradually, to a larger, better, more complete or more advanced stage. It implies growing or increasing, such that it brings forth full potentialities. In general, development is linked to the idea of progress; materially or otherwise. At the level of individuals, development implies increased skills and capacity, greater freedom, creativity, self-discipline, responsibility and material well-being (Rodney, in Adaja 2008).In national development discourse, development must manifest in a progressive manner, with evident improvement in the living standard of the people of a nation. This is why Soola (2003:13), while reviewing Oladipo's opinion about development, quotes him to have said:

Development in general is a process of economic and social advancement which enables people to realize their potentials, build self-confidence... a process aimed at freeing people from...want, ignorance, social injustice and economic exploitation.

In order to achieve and make effectively durable, developmental programmes must not just be made into administrative policies, they must continuously and realizably be sustainable. Such programmes must not only generate economic growth, they must distribute their benefits equitably and empower the people rather than marginalize them. It must give priority to the poor, enlarging their choices and opportunities and provide for their participation in decision affecting them. It is pro-poor, pro-nature, pro-jobs, pro-women and pro-children (Soola 2003:13).

For the development initiatives (in long or short terms) of a nation to become realised, the (entire) population must be carried along. Public communication programmes must be put in place to 
disseminate information that will let the citizens of the nation be intimated with such programme(s), its/their benefits and the roles that individuals and group need to play for the success of the initiatives. This is what Salawu (2008:17) refers to as Development Communication (DEVCOM)-"the application of the process of communication to development process".

Apart from being an alternative or addition to crude oil and gas as means of generating income, the film, in contemporary times, has become a veritable means through which governmental policies can be communicated to the Nigerian populace. This potentiality is yet to be fully annexed in Nigeria. In a global cinema survey conducted by UNESCO Institute of Statistics in 2009, Nollywood- the Nigerian film industry, has been adjudged to be the second largest producer of film in the world. Thus, Nigeria has edged out United States of America (Hollywood) which was before now second to India Bollywood. Apart from this rating, UNESCO has identified film and video productions as vehicles of identity, value and meanings, which can open the door to dialogue and understanding among peoples and foster economic growth and development (Alamu 2010:3-4).

Adagbada (2004) has pointed out the important role that the Nigerian film industry (Nollywood) play in alleviating to a very large extent, the problem of unemployment of graduates and school leavers in the country. Alamu (2010:6) too, has pointed out film and video as being good avenue for transmitting, expressing and preserving indigenous languages and cultural values. The studies of these scholars and others like them, still left a vacuum which this study intends to fill; a gynocentric inquiry into potentials of annexing the endeavours of the females as script writers, actresses, producers, directors, costumiers or make-over personnel in Nollywood, as an avenue by which Nigeria can communicate, realize her development initiatives and continuously sustain the realization.

The theoretical framework on which this study is hinged, is a combination of Womanismas opined by scholars like Kolawole (1997) and Clenora Hudson-Weems' (1996)opinion about the struggle of the African woman from male oppression, with Development and Media theory in the view of McQuail (2000), on the premise that the media is inevitable in accomplishing positive development through the communication of the developmental ambition of the governors, to the governed in a nation, such that they become aware of their roles in the bid to realize the goals.

\section{WOMEn, BIOLOGY AND SOCIETY}

The general view on the difference between men and women is that there are distinct significant and consistent biological differences between them. In Warton's (2005:18) view, this is sexual dimorphism; a biological factor by which a large majority of the world population categorize gender as male or female, according to how each appear physically. The common physical characteristic features are external and internal "genitalia, gonads that produce sex cells and secondary sexual characteristics" (Stollerin Haralambos et al 2008:93). Stoller however cautioned against the wide assumption that biological differences are responsible for the differences in the behavior of male and female thus:

Gender as a term that has psychological and cultural connotations; if the proper terms for sex are 'male' and 'female', the corresponding terms for gender are 'masculine' and 'feminine', these later might be quite independent of (biological) sex.

This is to say that the fact that a woman will definitely be 'feminine' or that a man must be 'masculine' is wrong. Girls are not necessarily 'caring' or boys definitely 'aggressive and competitive' (Haralambos et al 2008:93).

While Fausto-Sterling (2000:116) is highly critical of why only two sexes are recognized and opines that trans-sexual surgeries are unnecessary as a 'third' sex should be accepted, in most African societies, only male and female sexes are recognized. Any other specie of human form (or animal for that mater) will sound anomalous. This is unlike what obtains among some North American Indians (too), who recognize berdache as a third category of gender. They are "men who are treated in some way and acted like women. They are treated as a distinct gender" (Kessler and McKenna in Haralambos etal 2008:99)

In most societies of the world, the male is generally accepted as being superior to the female and as such he (the male) dominates the world. Patriarchy', literarily meaning 'rule by the father', is the concept which most encompassing explain gender inequalities. This concept, in the view of Haralambos et al (2008:91), has been in operation from the earliest times, for: 
...some Sociologists and Anthropologists believe that there does not exist and never has existed, a society in which women do not have inferior status to that of men

Otner in Haralambos et al (2008:105) and Oakley (2002) agree that women are universally oppressed and devalued. In their opinions, it is not biology (as opined by socio-biologists like Wilson and Barash (Haralambos et al 2008:95), that ascribes women to their status in the society, but rather, the way in which every culture defines and evaluates female biology.

The raison detrê and justification for the oppression and denigration of the female by the male has been theorized by many scholars. In Haralambos et al (2008:104-105), Firestone opines that it is as a result of biological differences. Otner believes that culture regulation is the reason, while Walby preferred paid work, relationship within the house, culture, sexuality, violence and the state as the reasons why women are oppressed. Adagbada (2005:14-32) too has discussed religious mythology about creation stories, inferior physiology, and psychological impression of 'Alterity'(self and other), as the primary reasons behind the subjugation of the female.

Ogundipe-Leslie (1994), Kolawole (1997), Adagbada (2005) and a host of other African women have examined various ways by which men oppress women and they advocate complementarity as the means by which both sexes can bring advancement to the society. On the other hand, scholars like Sofola (1994), Bateye (2002) and Mba (in Adagbada 2005:16) have argued that the African female has never been totally oppressed or marginalized by the male. In her own view, Oyewunmi (1997) has pointed out that the "Yoruba do not do gender", that socio-politically, both male and female have always had equal rights and recognition. Oyewunmi's (1997) view is similar to an earlier expression in Sofola's (1994:13) opinion that the Yoruba social order promotes a dual gender system of sociopolitical organization which permits a check and balance gender representation in governance. Sofola depicts the political structures of High Chief positions of (male) Lísà, Jọmu, Òdunwò, Òdộfinand Sàsẹẹeré in Ile-Oluji (in present Ondo State, Nigeria), before the advent of colonialism, as having equal female representations of Lísà-Lóbùn, Jomu-Lọbùn, Òdunwò-Lọ́bùn, Sama-Lọ́bùnand Ṣàsẹérẹ́Lọ́bùn $n^{2}$.Ọọ̀ni Lúwò (the monarch) of Ilé-Ifẹ̀ (in present Osun State, Nigeria), several years ago, was another female ruler pointed out by Sofola (1994). Falola (1991:76) has also pointed out that the 13th DéjiofÀkúrẹ was a female.

It should be noted that the leadership of these females was to a very large extent limited to their own gender. The female Ondo leaders exemplified by Sofola (1994) could only flex their muscles strictly in the market spheres, not generally within the town as a whole. Historical records show that Oọni Lúwò in Ilé-Ifẹ was not allowed to wear the traditional crown of a monarch like the male kings (Falola 1991:76). It will be wrong also, to use the experiences of princesses and privileged women to evaluate the position of all women in the society or to deny the collective subordination of women (BakareYusuf 2004).

\section{Religion AND ANDrocentric Colonial Heritage}

The political and economic gender imbalance mentioned above, is pointing at male dominance and superiority, coupled with the cultural and discriminatory practices inherent in traditional sex roles, division of labour and customary laws like bride-price, forced and girl-child marriage, polygamy, infibulations, excision and genital mutilation. All these made it possible for African men to exploit the super-imposition of the laws of the colonial masters to their advantage, by monopolizing power for themselves. This is because the colonial administrative set-up for instance, "allowed for the establishment of a male house of traditional African rulers, but not for their female counter parts" (Bateye 2002). The European value system that accompanied the colonial experience had no positive role for women.

Foreign religions that came alongside colonialism too, have in no small measure caused havoc to the socio-political structure in many African countries generally and Nigeria in particular. The male dominated orientation of Islam for instance has dislodged the female component of the social order prevalent before colonialism. According to Bateye (2002), prior to Islamization of the Hausa as a result of the 1804-1810 Jihad for instance, women had a measure of economic independence, whereby they owned farms and were self-employed. Intensive Islamization brought about rapid negative changes in the status of an average Hausa woman. She became voiceless and for a long time banned from holding political or economic offices "in adherence to Islamic injunctions". She has been 
relegated to servitude in the home where as a wife, she is not to be heard or seen by outsiders of the opposite sex. Her Christian sister too fares no better; she too can be seen but not heard (1 Corinthians 14:34-35).

\section{Resistance Against SubJugation ANd OPPRESSion}

The global oppression and denigration of women by the opposite sex has never been untrammeled by the victims. Women from Europe and North America are known to have resisted male oppression since a very long time, with the 1915 congress of women convened in the Hague being the most celebrated. The African women too, as pointed out by Kolawole, Sisga James and Ogundipe-Leslie (in Adagbada 2005) have never been silent over their oppression. Their voices can be heard clearly if one bothers to search through their literary creativities for instance. There have always been brave women who refused to accept the status quoand have challenged the position imposed upon them by cultural ethos. Some of such women were Efúnșetán Aníwúrà of Ìbàdàn, Àdùnní Olúwọlé and Madam Efúnróyè Tinúbú of Lagos, Inkpi of Igala and Queen Amina of Zaria (Awe 2000).

Adagbada (2006) is right to have pointed out that though the struggle against female denigration, oppression and marginalization is global, cultural differences, forms and manner of oppression, have necessitated the difference in the pursuit of rejection and as such the varieties of nomenclatures given the resistance across the globe. From the early 1970s, African women have felt the need to come together to fighttheir 'curse'by doing away with resistance premised on Western culture, framed from male perspectives and largely conducted by men. One of such bodies is the Association of African Women of Research and Development (AAWORD), located in Dakar,Senegal, the Harrare-based Trust Gender Project of South African Political Economy Series (SAPES), Women in Nigeria (WIN) and others like them.

Rupp (2002), in her examination of the first wave of international organizing of women's rejection across borders, rightly observe that:

The emergence of a bipolar world out of the ashes of war, the spread of national liberation movement throughout the formerly colonized countries and the emergence and resurgence of national women's movement around the globe in 1960s and 1970, profoundly transformed the context for international women's movement... Adding to the ... Pre-existing and emergent organizations, the United Nations-sponsored Decade for non-governmental gatherings, met in Mexico City in 1975, Copenhagen in $1980 \ldots$ Nairobi in $1985 \ldots$ Beijing Conference in $1995 \ldots$

The United Nations conferences on Women and particularly the Platform for Action, issued at the Beijing conference, had been very important. Consequent upon it, 'gender' has become a global issue on nations' policy agenda and gender study units and centres have sprang up.

Though scholars like Faludi (1992:1) and Greer (2000) are skeptic about women's victory from men's oppression, by and large, patriarchy has begun to loosen its grip on cultural ethos globally, though it still rears its ugly head somewhat slightly in few (developing) societies. However, some changes have transformed the lot of the female generally. Hakim (2004) believes that until recently, women did not have full equal opportunities with men, because a number of barriers made it difficult for all but a small minority to be able to pursue a career. She enumerates the contraceptive revolution of the pill, which allows for birth control, women's equal access to positions, occupations, and careers in the labour market, the expansion of white-collar occupations which has created a large reservoir of jobs for secondary earners in terms of period flexibility and personal preferences about work, as the five changes that have transformed the situation of the female for better.

Oakely (2002) is of the view that globally, the very old form of female oppression and patriarchy have to a reasonable extent disappeared; husbands and fathers cannot by and large any longer tell women what to do. The wages paid to employed women in Nigeria for instance, cannot be set according to the whims of (benevolent) sexist bosses in government establishments. Women in Africa more now than before, are bolder to seek redress at appropriate quarters if oppressed in any form. Furthermore, job opportunities have begun to open up for well-educated women as a result of the girl-child who now have equal educational opportunities with her male counterpart. All these have allowed the female to play more active roles in political, economic and social movement. This is why Ogundipe (2007:8) quotes Ibrahim to have said: 
Nigeria has moved forward now over the issues of women or has it not? We have since the eighties, genuine government efforts and regulations, even laws, to advance the position of women; women are more visible in positions of power and at institutions despite the appropriation of women's issues by military government and the proliferation of first lady movements.

The question now is that after her near-total (?) liberation from the oppression of the male, how best can the African female's sex and its associated potentials be fully annexed for sustainable development in a developing nation like Nigeria? This is because if the vacuum created by clipping the big, wide and oppressive wings of patriarchy is not filled with enduring and active participation of female-centred indispensible (potential) roles, which have been before now shielded with chauvinism Oakley's (2002:27) warning that patriarchy is the "default mode: what's always there and will always happen unless its actively contended", may come to pass.

\section{Projects ANd Initiatives Concerning Women}

Mohammed (2004) has pointed out that genuine development can only take place if there is conducive environment to peace and good governance. He enumerated ethnicity, religion, gender and allocation of resources in a way that leads to revolts and strifes as the bane of sustainable development in Nigeria. Gender, out of all these, Ogundipe (2007:7), in her reiteration of Mohammed's view, is very basic. She opines that women's political and economic empowerment is strategic to developmental issues in Africa. To her, African women are very empowered in many ways. The critical need today "is to include them and use their talents and resources". She says further:

Through the exclusion of women in decision-making roles in our national lives, we lose and waste a vast human resource that, if well-garnered, could help situate Nigeria and Africa properly and beneficially in world global systems.

One of the projects and initiatives that have been put in place for the recognition and integration of women's potentialities is the Global Gender and Economic Policy Management Initiative (GEMPI). It is a comprehensive capacity development and policy advisory services programme that aims to accelerate achievement of the Millennium Developmental Goals (MDGs), by making economic policies and poverty reduction strategies deliver results equitably to men and women, boys and girls. This project was designed by United Nations Development Programmes (UNDP) through regional partnerships, in order to respond to the national development frameworks. In collaboration with leading international and regional scholars, feminists, economists and policy makers, this global programme was designed with three major interconnected components; tailored country level advisory and capacity development workshop, immediate and specific capacity development and policy support to meet a country's particular need.

The Calvert Women's Principles (CWP) is another women's project. It is the first global code of corporate conduct focused exclusively on empowering, advancing and investing in women worldwide. The project was originally developed in partnership with UNIFEM (now United Nations Women) and was launched in 2004. According to its principles, pursing and supporting gender equity is not just about doing the right thing, it makes good business sense. The evidence for this position is in the 2010 study of a firm; McKinsey and Company. It was found out that companies with the highest share of women on executive committees out-performed those withall-male executive committees by $41 \%$ (as measured by return on equity) and 50\% (as measured by operating results).

\section{Gendering Nollywood Productions AND the ImPlications}

Ogundipe (2007) and Ilesanmi (2013) have pointed out the cultural empowerment of the (Yoruba) female as being 'sacred', considering her body, nudity, breasts, vagina and discharge of menstruation and breast milk. The highest notion of her sacredness is considered to be the ability to give life; a power which only God the Supreme Being, has. All these, the scholars claim, make women worthy of recognition as (potential) contributors to societal development. Ilesanmi (2013:169) submits that:

The elders know that women are gifted differently... As a matter of fact they are honoured for accomplishment in such fields as financing, marketing, midwifery, fashion designing, planning... 
Beside cultural beliefs, essentially, there should be sexing of work in labour market, because some jobs have gendered nature whereby there are jobs for men and jobs for women, such that the jobs cannot be filled by either sex.

While Gilmore (1990) suggests the three typical features of masculinity to be the impregnator, provider, and protector, Oakley (2002:38) discussing the impact for patriarchy on the social world as a whole from a radical feminists view, opines that masculinity is a threat (to the whole world). She believes that feminine values are in some ways superior and better. To her, masculine values lack "caring, empathy, compassion, altruism, and forgiveness", thus emphasizing the damage usually done by male violence in political, economic, social or religious administrations.

The African woman in the view of Womanists, does not intend to work separately from her male counterpart in her bid to contribute to and sustain her society's development. This is because the home is the nucleus of her society's socio-cultural set-up. All she is asking for is self-actualization and selfrecognition for her contribution (Adagbada 2006). Essentially, she wants to use her natural endowment, her innate ability to 'create' and nurture life, her empathetic, compassionate, sincere nature and ability to forgive more easily, to contribute her quota to the development of her society and the world as a whole. It must be noted that there is no divergence in this line of thought and action as regards her rejection of males' oppression, hence her struggles (Womanism) have no brands, unlike what obtains with Feminism in Oakley's(2002:37-38) view.

Adagbada $(2004 ; 2005)$ have brought to the fore, the position of the female in the metamorphic development of the Yoruba visual drama from religious festival drama era; through the itinerant masked dramaturgy of the Eégún Apidán; the stage performance of the Ogunde travelling theatre tradition; the celluloid and reversal stock film era; to the contemporary video-format film period. They have excelled as priestesses, chorus, welfare officers, and actresses in cliché roles and as travelling theatre proprietress ${ }^{3}$. In present times, they play full roles in characterization as they observe in the realities of life, as actresses. They are also script writers, prolific producers, directors, and executive producers of films. Idowu Philips, Bukky Wright, Taiwo Akinwande, Joke Muyiwa, Laide Bakare, Iyabo Oko, Modupe Johnson, Liz Anjorin, Remi Oshodi, Bisi Komolafe, BisilbidapoObe, Sola Asedeko, Peju Ogunmola, RonkeOjo, Sola Sobowale, Lola Alao and Dupe Jayesinmi are just very few of the several women who are household names in the (Yoruba) Nigerian film industry.

Nigeria is presently experiencing myriad of socio-political and economic challenges. Some of these are corruption, religious intolerance, threatening secession from the eastern part, boundary clashes, cultism in academic institutions and vandalization of public properties. Several attempts by internal and international corporate bodies to combat these challenges have not been much of a success. It appears as if these ills have eaten deep into the very fabric of the nation, such that the psyche of individual Nigerians need to be touched, to effect the desired changes that can bring about development. It will be unrealistic to have a one-on-one discussion with individual Nigerian citizens for a meaningful re-orientation. This is where the use of "popular theatre" comes in (Lawal 2015: 185-189).

Presently, the film (in the video format), which can be watched conveniently in individual homes and even on the cheapest mobile phone, apart from doing so in theatres and cinema houses, is the 'popular theatre' in Nigeria (Adagbada 2015;2010; Alamu2010:4-11). Essentially therefore, gendered film production becomes indispensible if effective appeals to the masses for positive change of attitude towards building a unified, progressive and virile nation is to be achieved by collective actions. Thus, government policies and strategies can be made known to the public through encouraged, assisted/or directly commissioned films produced by female film professionals. An examination of the themes and sub-themes of some of the few films that females in Nollywood have dared to produce through self-efforts, to influence collective steps towards re-orientation, will make it evident that gendering productions in Nollywood, especially towards general sustainable development, is a worthy course. With what Bukky Wright and Akowonjo Bintu have done in Dùgbè Dùgbẹ tó ń bọ (Impending doom) and Omo Orita (Gangsters) respectively, much will be achieved in diverting the attention of Nigerian youths away from robbery, cultism, political thuggery and rape, if films with related themes or subthemes are commissioned to them for production. Opéyẹmí Ayéọla Olowomonse's production of Jayéoba (Enjoying the bliss of royalty) qualifies her for assistance or sponsorship of films whose themes can be used to point out those aspects of monarchy that have continually being the bane of successful democratic governance in Nigeria. Jógunómí (Let peace reign) by Anike Obot, is also a 
pointer to the fact that films produced by females will awaken Nigerians to the possibility of living in a peaceful, united, terrorism-free and progressive nation, ruled by non-corrupt and selfless leaders.

Other films that are similar to the ones exemplified above, include Sola Sobowale's Ayọ Mi Dà? (Whence my joy?) and Fathia Balogun's lead role in Símisọlá ôtẹlẹmúyè (Simisola the Detective Police) which are convincingly pointing to the fact that (Yoruba) female film practitioners have what it takes, given an enabling environment, to produce films that can appeal to the conscience of kidnappers. The case of almost three hundred kidnapped girls from Chibokfor instance, comes readily to the mind here ${ }^{4}$. Laide Bakare's Ewé Ojú Omi (Drifting leaf on the surface of water), is a lesson against electioneering vices like stealing ballot boxes and mishandling ballot papers during political transitions. This producer can be given or commissioned to produce films that can sensitize the citizenry to government's policies in carrying out successful elections.

\section{Conclusion}

In this study, we have examined scholars' views on gender, apart from examining the place of the female in socio-political situations, especially among the Yorùbá, as being a second fiddle if compared with the male. We have also theorized the raison detrê for her marginalization alongside her struggles for emancipation. We pointed out the fact that in present times, the female is free from (severe) oppression by males. We analyzed the issue of relativity by saying that now that she has equal rights with her counterpart, her sexuality should be annexed for the sustainable development of the society. Our point of reference is the female practitioner in the Nigerian film industry (Nollywood), whose 'sacred' mien and untapped potentials should be used in finding solutions to the socio-political challenges facing Nigeria. Our suggestions are that government and non-profit organizations should endeavour to commission films whose themes can ginger viewers individually and collectively, to have change of attitudes toward issues which have been heretofore causing seclusion, renunciation, rifts, insurgencies through exhibition of volatile anger and the likes. Female film producers too must be patriotic by giving priority to contributing to the enhancement of sustainable development of Nigeria through writing film scripts and playing roles in films that can bring about the desired changes, so that government and non-profit organization can invest in/or assist them. They need to come together under an association to make their needs felt and be able to speak in one voice. They also need to put projects and initiatives concerning film productions for national development, in place.

\section{Notes}

1. The term 'patriarchy' was first used by Kate Millet (1970) in Sexual Politics. (See Haralambos et al 2008:108-109).

2. The appellation "Lọ́bùn" is morphologically derived from ní+ọbùn (in+market). Among the (Yorùbá) Africans, the number of females in a normal (open) market setting is usually higher than that of men. This is because buying and sellingis socio-culturally accepted as a sphere for the female. It is however not out of place to find few men as traders or shoppers in a market.

3. Adagbada (2005:76) has pointed out late Olufunmilayo Baloguna.k.a Funmilayo Ranko as one female who was the proprietress of Funmilayo Ranko Travelling Theatre.

4. On the night of 14th - 15th April, 2014, 276 female students were kidnapped from the Government Secondary School, Chibok, in Borno State, Nigeria. Boko Haram, an extremist and terrorist organization, claimed responsibility for the incidence.

\section{REFERENCES}

Adagbada, Olufadekemi, (2004). "Eré Oníșe Yorùbá gẹegẹ bí Orísun Okòwò". OYE: OgunJournal of Arts. The Faculty of Arts, OlabisiOnabanjo University, Ago-Iwoye, Ogun State, Nigeria. X:5470

Adagbada, Olufadekemi, (2005). "Women folk in the Yoruba Video Film Industry".Ph.D Thesis submitted to the Department of Linguistics and African Languages, University of Ibadan, Nigeria. 
Adagbada, Olufadekemi, (2006) "Women, Oppression, its Rejection and Nomenclature in Yoruba Video Films". Journal of Philosophy and Development. Faculty of Arts, Department of Philosophy OlabisiOnabanjo University, Ago-Iwoye, Ogun State, Nigeria. 8, (1x2) : 105-121.

Adagbada, Olufadekemi, (2015) "Traditional and Contemporary Ethnic Disposition to Women as Leaders in Yoruba Films". International Journal of Humanities, Social Sciencesand Education. Hyderabad: Academician Research Centre. 2.(1) :72-82.

Adaja, Tokunbo A. (2008) "Development Communication: Structural Prerequisites and Strategies for Third World Nations". Journal of Philosophy and Development, Faculty of Arts, OlabisiOnabanjo University, Ago-Iwoye, Ogun State, Nigeria, 10 (1x2): 120-130.

Alamu, O.A. (2010). Aesthetics of Yoruba Film. Osaka: Research Institute for World Languages.

Awe, Bolanle (2000) ed. Nigerian Women in Historical Perspectives Lagos: Sankore Book craft.

Bakare-Yusuf, Bibi(2004). 'Yorubas Don't Do Gender': A Critical Review of Oyeronke Oyewunmi's The Invention of Women: Making an African Sense of Wester Gender Discourses'. African Gender Scholarship: Concepts, Methodologies and Paradigms. Dakar: Council for the Development of Social Science Research in Africa (CODESRIA): 61-81.

Bateye,Bolaji (2002), "Reclaiming a Lost Tradition: Nigerian Women in Power and Resistance". Women and the Culture of Violence in Traditional Africa. Eds Akintunde Dorcas and HellenLabeodan. Ibadan: Sefer books: 79-91.

Falola, Toyin (1991).Yoruba Histriography. Madison: University of Wisconsin African Studies Programme.

Faludi, Susan. (1992). Backlash: The Undeclared War against Women. London: Chatto\&Windus.

Fausto-Sterling, A.(2000). Sexing the Body:Gender Politics and the Construction of Sexuality. New York: Basic Book.

Gilmore, D. (1990). Manhood in the Making: Cultural Concepts of Masculinity. New Haven: Yale University Press.

Greer, G.(2002). The Whole Woman. London: Anchor.

Hakim, Catherine (2004). Key Issues in Women's Work: Female Diversity and the Polarisation of Women's Employment. London: Glasshouse Press.

Haralambos, M., Holborn, M. and Heald, R. (2008) Sociology: Themes and Perspectives 7th edn. London: Harpercollins.

Hudson-Weems, Clenora.(1993) Africana Womanism. Troy: Bedford Publishers.

Ilesanmi, T.M. (2013) OBINRIN: A Cultural Assessment of Yorùbá Women. Ife: Astraly Multimedia.

Kolawole, Mary M. (1997). Womanism in African Consciousness. New York: Africa World Press.

Lawal, Hakeem O. (2015). Fundamentals of Theatre Arts. Ibadan: Daybis.

Mc Quail, D. (1972) The Sociology of Mass Communication: Harmonds Worth: Penguin.

Mohammed, A. A. (2005) 'Opening Speech'. CBACC: Communique on Pan Africanism and the African Diaspora. Lagos: Malthouse.

Oakley, Ann. (2002). Gender on Planet Earth. Cambridge: Polity Press.

OgundipeMolara. (2007). Indigenous and Contemporary Gender Concepts and Issues in Africa: Implications for Nigeria's Development. CBACC Occasional Monographs. Lagos: Malthouse.

Ogundipe-Leslie M. (1994). Re-Creating Ourselves: African Women and Critical Transformation. New York: Africa World Press.

Oren, Dorrel. (2014) "Terrorist Kidnap more than 200 Nigerian girls". https//en.wikipedia.org/wiki/ chibok_schoolgirls_kidnapping

Oyewunmi, Oyeronke (1997). The Invention of Women: Making an African Sense of Western Gender Discourse. Minneapolis: University of Minnesota Press.

Rupp, Leila J. (2002). “The International First Wave”. An Introduction to Women's Studies. Gender in a Transnational World. eds Grewal, Inderpal and Kaplan Caren. New York: McGraw-Hill Higher Education. : 248-251.

Salawu, A. (2008)"Development Communication: the Preliminaries". Globalization and Development Communication in Africa. (eds) Mojaiye, E.M et al. Ibadan: Ibadan University Press. 
Sofola, Zulu, (1994) "Feminism and the Psyche of African Womanhood". Paper presented at the First conference on Women in Africa and the African Diaspora. University of Nigeria Nsukka.

Soola, E.O. (2003). "Perspectives on Development Journalism".Communicating For Development Purposes. (ed.) Soola, E.O. Ibadan: Kraft Books.

Warton, A.S. (2005) The Sociology of Gender. Malden: Blackwell.

\section{AUTHOR's BIOGRAPHY}

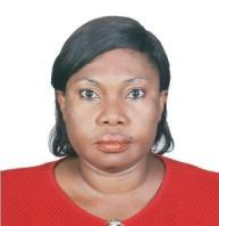

Adagbada Olufadekemi (PhD), is an Associate Professor in the Department of Nigerian and Foreign Languages and Literatures of the Faculty of Arts, Olabisi Onabanjo University, Ago-Iwoye, Ogun State, Nigeria. Her area of study is Drama in Yoruba Literary Studies with a bias for Gender Studies in Films and Texts. She is currently the Head, Department of Performing Arts in her University. 